\title{
Dansk med måde
}

\section{Henrik Høeg Müller}

\begin{abstract}
The purpose of this paper is to show that the use of manner verbs differs systematically between Danish and Spanish, and that this factor exercises a decisive influence on their clause formation and distribution of semantic content across linguistic units. It is argued that in Danish, due to its strong preference for using manner verbs as main predicates, the semantic component MANNER becomes the core information which frames the expression of the event, while in Spanish the manner in which an event evolves is usually not mediated linguistically as a central component of the clause, if expressed at all. Consequently, speakers of Danish focus on events as visual manifestations of reality, while speakers of Spanish are not attuned to conceptualizing events visually.
\end{abstract}

\section{Nøgleord}

begivenheder, germanske vs. romanske sprog, MÅDE og RETNING, typologi, verber, visualisering

\section{Indledning}

Formålet med denne artikel er at vise, at brugen af verber, der udtrykker måde, er systematisk forskellig mellem dansk og spansk, og at det har en afgørende indflydelse på disse sprogs sætningsdannelse og fordeling af semantisk indhold på tværs af sproglige enheder (Müller 2014). ${ }^{1}$ Dansks udprægede tendens til at anvende verber, der udtrykker måde, som sætningens hovedverbum, bevirker, at den semantiske komponent MÅDE bliver den kerneinformation, der i vid udstrækning er bestemmende for begivenheders sproglige udformning. Modsat forholder det sig med spansk, hvor måden,

1 Se også fx Slobin (2004) og (2006) vedr. mådeudtryks fremtrædende rolle i visse sprog. 
en begivenhed er eller udvikler sig på, normalt indtager en langt mindre indflydelsesrig position i sætningen.

Jeg vil på det grundlag - og i overensstemmelse med Herslund \& Barons (2005) leksikalsk-typologiske teori vedr. kontrasterne mellem endo- og exocentriske sprog - argumentere for den antagelse, at dansk- og spansktalende skaber forskellige mentale repræsentationer af virkeligheden. Uden at have eksperimentelt belæg for det er idéen, at dansktalende generelt fokuserer på begivenheder som visuelle manifestationer af virkeligheden (Baron 2014: 298f.) - man forestiller sig altså konkret, hvordan en figur bevæger sig eller er placeret ift. grunden - mens spansktalende snarere opfatter begivenheder som abstrakte aktiviteter eller positionelt non-specifikke relationer mellem figur og grund.

\section{Baggrund}

Inden for den traditionelle komparative lingvistik har kontrasterne mellem germanske og romanske sprog, især med hensyn til udtryk for bevægelsesbegivenheder i tysk og fransk, været genstand for opmærksomhed gennem mange år (se fx Strohmeyer 1924, Malblanc 1944, Bergh 1948 og Vinay \& Darbelnet 1958). For eksempel henleder Strohmeyer (ibid.: 191-192, citeret i Woldersgaard 2017: 13-14) opmærksomheden på den leksikalske asymmetri, der findes mellem franske og tyske bevægelsesudtryks specialiseringsgrad, når han nævner, at det franske verbum aller 'gå' svarer semantisk til en række forskellige tyske verber, såsom gehen 'gå', fahren 'køre', reiten 'ride', fliegen 'flyve', segeln 'sejle' etc. Samtidig peger han på, at de tyske verbers såkaldt specialiserede betydning ofte udtrykkes på fransk af andre typer bevægelsesverber, såsom entrer 'bevæge sig ind' og sortir 'bevæge sig ud', uafhængigt af den specifikke bevægelsesbegivenheds udfoldelse, dvs. den måde, den foregår på, samt aktanternes karakteristika og konfiguration i øvrigt.

Det er imidlertid først med Talmy (fx 1985), at forskellige måder at udtrykke bevægelsesbegivenheder på beskrives som systematiske typologiske kontraster mellem sprogs foretrukne konstruktionstyper. Kort fortalt arbejder Talmy med fire slags semantiske komponenter: 1) Figur: den entitet, der bevæger sig eller befinder sig et sted; 2) Grund: den entitet, som fungerer som spatialt referencepunkt for figurens bevægelse eller lokation; 3) Retning: den bevægelsesretning eller -bane, som figuren følger; og 4) Måde: den måde, 
hvorpå figuren bevæger sig. ${ }^{2}$ Ud fra hvilken semantisk komponent der inkorporeres i verbet, opstiller Talmy tre konstruktionstyper: mådesinkorporerende, retningsinkorporerende og grundinkorporerende. ${ }^{3}$ Dette fører til, at de germanske sprog i hovedtræk opfattes som mådesinkorporerende, mens de romanske regnes for retningsinkorporerende.

Senere udvider Talmy (fx 2000) sin typologi, så den ud over bevægelseskonstruktioner også omfatter resultative konstruktioner à la han maler huset rødt, og vigtigst af alt udvikler han den idé, at alle komplekse begivenheder grundlæggende består af en såkaldt rammebegivenhed, framing event, som tilfører den komplekse begivenhed den mest centrale information - udgør rammebetingelserne om man vil - og en medbegivenhed, co-event, der tilføjer mindre vigtig, udenomsinformation. Følgende eksempler fra dansk og spansk illustrerer disse begrebers anvendelse på en kompleks bevægelsesbegivenhed, hvor rammebegivenheden er markeret med fed og understregning, mens medbegivenheden er markeret med fed.

(1) Ole svømmede over Guadalquivir.

$\begin{array}{lllll}\text { Ole } & \text { cruz-ó } & \text { el } & \text { Guadalquivir } & \text { nad-ando. } \\ \text { Ole } & \text { krydse-PST } & \text { ART } & \text { Guadalquivir } & \text { svømme-GER }\end{array}$

Som det fremgår af eksemplerne, definerer Talmy inden for bevægelseskonstruktioner betydningskomponenten RETNING som rammebegivenhed, og komponenten MÅDE som medbegivenhed. Dette fører i sidste ende til, at de germanske sprog klassificeres som S(atellite)-framed, idet de prototypisk udtrykker RETNING i en satellit (fx en verbalpartikel), mens de romanske sprog klassificeres som V(erb)-framed, da RETNING som hovedregel realiseres i disse sprogs verbale rod. Det betyder, at i Talmys udspil fra 2000 til en typologi baserer kontrasteringen af sprog sig på, hvorvidt betydningskomponenten RETNING indkodes i en satellit eller en verbalrod (se også Morita 2011).

Talmys typologiske tilgang er i hvert fald de seneste 10-15 år blevet kritiseret ud fra en række perspektiver, og mere eller mindre omfattende ændringer og præciseringer er blevet bragt i forslag (se fx Slobin 2004, Pedersen 2009, Beavers et al. 2010, Croft et al. 2010, Müller 2014). Det problem, som er fokus for denne artikel, er, at Talmys tertium comparationis - dvs. forskellige måder at kode bevægelsesbegivenheder på i henhold til sprogs strukturelle

2 Se fx Croft et al. (2010: 201-205) for en mere omfattende udlægning af Talmys tidlige idegrundlag.

3 Den sidste type er ikke relevant her. 
realisering af RETNING - ikke giver et retvisende "typologisk" billede af dansk og de konsekvenser, som MÅDE-komponentens fremtrædende rolle har for sætningsdannelse og opfattelsen af begivenheder. ${ }^{4}$ Hertil knytter sig så yderligere det aspekt, at Talmys meget indflydelsesrige typologi, såvel som den store mængde litteratur om bevægelsesbegivenheder, den har genereret, synes at have ført til den forholdsvis udbredte antagelse, at mådesudtryk er undergivet, hvordan bevægelsesbegivenheder kodes sprogligt (se fx Akita 2017). Som tidligere nævnt betragtes mådesudtryks prominente rolle i visse sprog imidlertid i denne artikel som et af bevægelsesbeskrivelser uafhængigt, selvstændigt fænomen (se Slobin 2004 og 2006 for et tilsvarende synspunkt). Kort fortalt er en af de centrale udfordringer ved Talmys tilgang derfor, som jeg ser det, at udtryk for bevægelsesbegivenheder bliver typologisk definerende for dansk, og at MÅDE-komponentens helt afgørende betydning samtidigt overses.

\section{Specifikke vs. generelle verber}

Ifølge Herslund (2014: 75) er det en grundlæggende forskel på de germanske og de romanske sprog, at de romanske anvender langt flere generelle verber end de germanske. Herslund (ibid.: 76) beskriver generelle verber som denoterende begreber, hvis definition indeholder relativt få semantiske træk, dvs. at begreberne har en reduceret intension. Dette indebærer, at den mængde entiteter, som falder ind under de generelle begreber, er relativt stor, dvs. at de har en bred ekstension. Modsat har specifikke verber en rigere intension forstået på den måde, at mængden af træk, der definerer begrebet, er større, hvilket så på den anden side resulterer i en snævrere ekstension. Et begrebs ekstension er altså en konsekvens af og omvendt proportional med dets intension. Forskellen mellem dansk og spansk for så vidt angår anvendelsen af specifikke vs. generelle verber illustreres af eksemplerne i (3) og (4). ${ }^{5}$

4 Paradoksalt nok ville den tidlige version af Talmys typologi, der jf. beskrivelsen ovenfor opererer med mådesinkorporerende sprog, nok være mere adækvat i forhold til at give et retvisende billede af dansk som sprogtype.

5 De dele af eksemplerne, der er relevante i den specifikke kontekst, markeres med fed gennem hele artiklen. De spanske eksempler glosseres generelt ikke, dels af overskuelighedsgrunde og pladshensyn, dels fordi de er indholdsmæssigt parallelle til de danske. Endelig skal det nævnes, at visse af eksemplerne i (3) også er anvendt i Müller (2014: 126). 


\author{
[Dansk] \\ Gud skabte mennesket. \\ Træet kaster skygge. \\ Høns siger gok, gok. \\ Ole lægger kabale. \\ Ea slår/borer/hugger/ \\ saver et hul i væggen.
}

[Dansk]

Hun satte retten ind i ovnen. Hun hælder meget olie i mayonnaisen.

Han hænger jakken ind i skabet.

Han stak hænderne i lommen. Han stopper bukserne ned i støvlerne.

\section{[Spansk]}

Dios hizo al hombre.

El árbol hace sombra.

Las gallinas hacen clo, clo.

Ole hace solitario.

Ea hace un hueco

en la pared con un martillo, un taladro, un hacha, una sierra. 'Ea laver et hul i væggen med en hammer, et bor, en økse, en sav.'

\section{[Spansk]}

Metió el plato en el horno.

Mete mucho aceite en la mayonesa.

Mete la chaqueta en el ropero.

Metió las manos en el bolsillo.

Mete los pantalones en las botas.

De danske verber har et højt semantisk specificitetsniveau, da de mere eller mindre direkte udtrykker den måde, hvorpå de relevante verbale aktiviteter udføres. De pålægger deres interne argumenter (her det direkte objekt) semantiske restriktioner og har derfor et relativt begrænset anvendelsesområde i forhold til typen af situationer, de kan beskrive. De spanske modstykker, verballeksemerne hacer 'gøre' og meter 'anbringe', indeholder derimod ikke nogen form for MÅDE-komponent, hvilket betyder, at de kan indgå i konstellationer med alle argumenter uafhængigt af disses referentielle eller semantiske "beskaffenhed". De spanske verber denoterer således en generel aktivitet, der kan dække mange forskellige situationer beskrivelsesmæssigt (se Müller 2014: 127). Samtidig kan man konstatere, at eksemplerne i (3) og (4) jo ikke refererer til, hvad man traditionelt forstår ved bevægelsesbegivenheder, men derimod "gængse" transitive situationer.

Som eksemplerne i (5) viser, er billedet, ganske som vi kunne forvente, det samme, når der er tale om den slags begivenheder, hvor subjektsreferenten bevæger sig i en retning mod et mål. Fænomenet vedr. forskelle i hovedver- 
bets semantiske specificitet i form af inkorporering af MÅDE-komponenten eller ej er som sagt bare ikke begrænset til denne snævrere kontekst.

\author{
[Dansk] \\ fisken svømmede ind \\ fuglen fløj ind \\ bilen kørte ind \\ skibet sejlede ind
}

(Müller 2014: 125-126)

\author{
[Spansk] \\ el pez entró \\ el pájaro entró \\ el coche entró \\ el barco entró
}

De danske verber integrerer BEvÆGELSE og MÅDE i deres leksikalske rod og udtrykker i kombination med retningspartikler (her ind) en bevægelsesbegivenhed, mens spansk for at udtrykke den samme type begivenhed bruger verber, der inkorporerer BEVEGELSE og RETNING i roden. På grund af deres høje grad af specificitet pålægger de danske verber også her det interne argument (i dette tilfælde det intransitive subjekt) restriktioner, hvilket betyder, at subjektsreferenten skal være forenelig med den måde, bevægelsen udføres på (svømme, flyve, sejle etc.). Modsat indeholder det generelle spanske verbum entrar 'bevæge sig ind' ikke oplysninger, der indsnævrer dets potentiale til at kombinere med enhver referent, der er i stand til at udføre en bevægelse.

Det er vigtigt at bemærke, at de romanske sprog, ligesom dansk, rent faktisk disponerer over en stor mængde bevægelsesverber, der beskriver måden, hvorpå en figur bevæger sig i forhold til en grund, men at de normalt kun fungerer som rene aktivitetsverber (jf. Vendlers 1967 eventmodel). Det vil sige, at de som oftest ikke anvendes telisk til at beskrive en ændring i en entitets position eller beskaffenhed. Forskellen mellem dansk og spansk i forhold til fordeling af semantisk indhold på tværs af sproglige enheder i sætningen er således ikke bare et leksikalsk spørgsmål om, hvilke semantiske komponenter der er integreret i verbet, men lige så meget et spørgsmål om at tage hensyn til den egentlige brug af de leksikalske enheder. ${ }^{6}$

Ud over det rene semantiske perspektiv vedr. selektionsrestriktioner, så er en yderligere, og naturligvis beslægtet, konsekvens af de danske verbers

6 Dansk har en række deiktiske verber, såsom (an)komme, drage, begive sig og vende, der leksikaliserer BEVÆGELSE, men ikke MÅDE. Disse verber udtrykker dog stadig RETNING gennem en partikel (satellit) og adskiller sig dermed fra de typiske romanske verber, der udtrykker både BEVÆGELSE og RETNING i roden (se Müller 2014: 199, note 3). 
høje specificeringsniveau, at danske verbale udtryk er langt mere følsomme i forhold til den ekstralingvistiske kontekst, de optræder i.

Eksemplerne i (6) viser tre typer danske verber, som pga. deres leksikalske specificitet, foruden at pålægge det interne argument restriktioner, også mere generelt interagerer med - eller man kunne sige, at deres anvendelse er bestemt af - ikke-sproglige kontekstuelle faktorer såsom visualisering af situationen. Igen er de tilsvarende spanske udtryk generelle og dermed neutrale over for ændringer i vores visuelle opfattelse af eller viden om fænomener i den ikke-sproglige verden.

[Dansk] [Spansk]

(6a) Rul vinduet ned.

(6b) Ea drejer/taster hans nummer.

(6c) Fluen sidder $/ *^{*}$ står på bordet.
Baja la ventana. (bajar: bevæge ned) Ea marca (marcar: markere)

su número.

La mosca está (estar: være/ befinde sig) en la mesa.

Den danske resultative konstruktion i (6a) beskriver den måde, hvorpå en subjektsreferent opfordres til at udføre aktiviteten at åbne et vindue $\mathrm{i}$ en bil af ældre dato, altså ved manuelt at dreje et håndtag. I modsætning hertil indeholder det generelle spanske verbum bajar i den tilsvarende konstruktion ingen oplysninger om, hvordan bevægelsen skal udføres. Så sådan lidt populært sagt, er vi i Danmark nødt til at skrifte (mådes)udtryk, når teknologien udvikler sig, mens det for spansktalende ingen betydning har ud fra et sprogligt perspektiv.

Det næste eksempel er parallelt. På grund af deres MÅDE-komponent kan de danske transitive aktivitetsværdier dreje og taste ikke bruges til at beskrive den samme situation. Brug af dreje kræver henvisning til en drejeskivetelefon, mens taste indebærer, at den pågældende telefon har nogle knapper, man kan trykke på. Det spanske verbum marcar derimod leksikaliserer ikke MÅDE, og derfor er dets anvendelse ganske upåvirket af telefonens indretning. Vi har altså på dansk i takt med den teknologiske udvikling måttet skifte verbalt udtryk for at give visuelt og situationsmæssigt adækvate beskrivelser af de pågældende aktiviteter, mens spansktalende bare har kunnet fortsætte uanfægtet.

Endelig illustrerer det sidste eksempel, at selv danske statiske positionsverber indeholder MÅDE, og følgeligt skal referenten også i disse tilfælde svare til den måde, som verbet angiver. Ifølge Hansen (2001/[1974]: 147), som jeg vender tilbage til, forholder det sig sådan, at små dyr som fluer 
og edderkopper sidder, mens større dyr som fx køer står, medmindre en bestemt kontekst angiver noget andet selvfølgelig. På spansk - og de øvrige romanske sprog - ville den mest naturlige formulering uden tvivl være en med et mådesneutralt positionsverbum som estar 'være' eller encontrarse 'befinde sig', hvis anvendelse er helt uafhængig af subjektsreferentens størrelse eller øvrige beskaffenhed.

\section{MÅDE-verbernes anvendelse}

Formålet med dette afsnit er yderligere at kvalificere den i indledningen fremsatte påstand, at danske verber, der udtrykker måde, anvendes bredt, kreativt og fleksibelt som leksikalske hovedverber i sætningsdannelsen, mens dette ikke gælder for de tilsvarende spanske verber.

\subsection{Udvidelse af argumentstrukturen (afledt valens)}

Danske aktivitetsverber er fleksible med hensyn til den argumentstruktur, de er i stand til at projicere. (7) viser, hvordan en række inergative, mådesinkorporerende aktivitetsverber, der normalt implicerer figurens / subjektsreferentens bevægelse væk fra udgangspositionen, er blevet transitiverede og samtidig tager et tredje argument i form af et retningsangivende PP-komplement (til Málaga) (se også Müller 2014: 127ff.).

Ana
*Ana

ror/ kører/ flyver/ sejler/ cykler

\section{rema/ conduce/ vuela/ navega/ pedalea}

Juan til Málaga.

a Juan a Málaga.

De parallelle eksempler i (8) må regnes for ugrammatiske, idet de betydningsmæssigt tilsvarende spanske verber generelt er "fastlåste" i deres oprindelige intransitive valensskema.

Herudover viser eksemplerne i (9) og (10), hvordan andre typer aktivitetsverber, der ligeledes leksikaliserer MÅDE, men ikke indebærer en bevægelse væk fra udgangspositionen fra subjektsreferentens side, undergår ændringer i deres valensstruktur, her manifesteret som en refleksiv, intransitiv struktur med subjektsprædikativ, som i (9), og en transitiv struktur med objektsprædikativ, som i (10). Begge denoterer såkaldte "change of state"-situationer i Levin og Rappaport Hovavs (1995) forstand (se også Korzen 2004 for en udlægning af disse strukturer på dansk). 
(9) Brudgom løj sig død for at slippe for brylluppet. www.udeoghjemme.dk (20. august 2014)

(10) Man kan ikke stege kødet mørt, kun mere tørt. www.dindebat.dk (19. januar 2007)

Som nævnt er denne mulighed for at modificere valensrammen hos forskellige danske verber, der har det tilfælles, at de leksikaliserer MÅDE, generelt ikke til stede på de romanske sprog, og samtidig kan den opfattes som en indikation på, hvordan man på dansk og andre germanske sprog kan prioritere at udtrykke MÅDE i sætningens centrum i stedet for i dens periferi, som det fx er tilfældet i en kausativ konstruktion à la man kan ikke gøre kødet mørt ved at stege det, kun mere tort. Selv om de romanske sprog, herunder spansk, råder over "change of state"-konstruktioner (af nogen beskrevet som resultative eller kausative), der ligner de germanske, som fx pintar la ropa azul 'farve tøjet blåt', anses det for et relativt marginalt fænomen, absolut ikke et systematisk, produktivt system som på dansk (se fx Korzen 2003: 85-89). Eksempel (11) viser, at det fx ikke kan lade sig gøre at modificere det spanske verbum freír's 'stege' valensramme analogt med det danske eksempel (10).

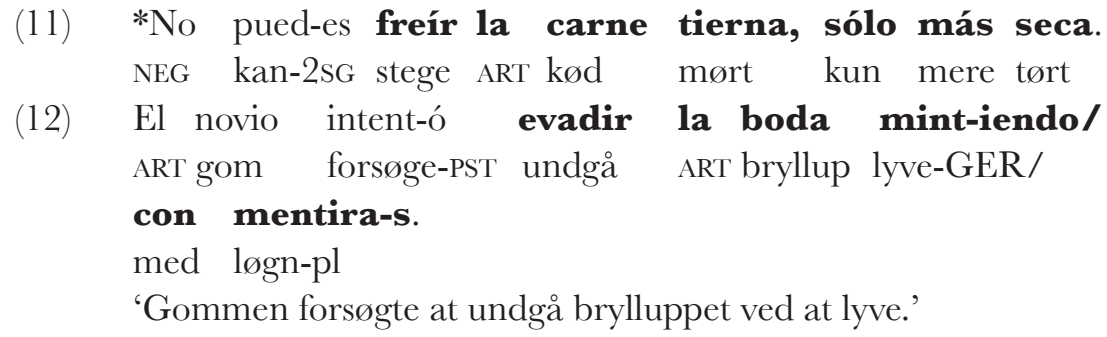

Eksemplet i (12), som er delvist parallelt til (9), dog uden subjektsprædikativet $d ø d$, har jeg medtaget for at vise, at MÅDE-komponenten som standard på spansk og andre romanske sprog udtrykkes i periferien af sætningen med en gerundium eller et PP-komplement, jf. også eksempel (2). ${ }^{7}$

7 Det er selvfølgeligt muligt også på spansk at anvende mentir 'lyve' som hovedverbum i en konstruktion, der gengiver indholdet i (9) nogenlunde dækkende, som fx mintió con su propia muerte para evadir la boda 'han løj med sin egen død for at undgå brylluppet'. Pointen er imidlertid, at der på spansk er tale om en fri beskrivelse og ikke som på dansk et konstruktionsmønster, der indebærer, at man kan lyve sig alt muligt forskelligt, såsom yngre, ældre, rig etc. 


\subsection{Positionsverber}

På dansk anvendes positionsverber ofte i serieverbekonstruktioner, som i forhold til grammatisk aspekt udtrykker varige, ikke-teliske begivenheder, jf. a-eksemplerne nedenfor.

(13a) Hun læser.

(13b) Lee.

(14a) De synger.

(14b) Cantan.

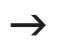

$\rightarrow$
Hun sidder og læser.

Está leyendo.

De står og synger.

Están cantando.

Det, der er vigtigt at påpege, er, at det specifikke valg af positionsverbum ikke er tilfældigt, men afhænger af subjektsreferentens reelle position i den virkelige verden. Det ville være pragmatisk afvigende i forhold til kommunikationssituationen, hvis fx sidde eller ligge anvendtes i situationer, hvor subjektsreferenten rent faktisk udførte den pågældende aktivitet i stående tilstand. Så også her skal, hvad der i bred forstand kan beskrives som de fysiske omstændigheder ved situationen, i dette tilæælde subjektsreferentens position, være forenelige med den MÅDE-komponent, som udtrykkes i de specifikke positionsverber, for at hele udtrykket er en visuelt og situationsmæssigt afstemt beskrivelse af virkeligheden, jf. også den tidligere diskussion af eksemplerne (6a), (6b) og (6c).

De spanske paralleleksempler, (13b) og (14b), peger på, at man på spansk i tilsvarende situationer naturligt ville fokusere på det imperfektive aspekt, som strukturen udtrykker, og anse den måde, som subjektsreferenten er placeret på, for helt irrelevant. Derfor er de tilsvarende udtryk på spansk her angivet som en variation mellem præsens og progressivt aspekt i form af hjælpeverbet estar 'være' i kombination med gerundiumsformen af det pågældende aktivitetsverbum, fx leyendo 'læsende' som i (13b).

Også når de danske positionsverber anvendes i statiske beskrivelser, spiller MÅDE-komponenten en central rolle.

(15) Bogen står i reolen/ ligger på bordet.

(16) Glassene står/ ligger på bordet.

(17) Hvor sidder kontakten?

Grundprincippet er, at hvert positionsverbum dikterer forskellige fortolkninger af, hvordan subjektsreferenten, dvs. figuren, er rumligt placeret i forhold til referenten for præpositionskomplementet, altså grunden. Brugen 
af stå indikerer, at subjektsreferenten, bogen i (15), står i en lodret stilling på hylden, mens ligge jo indebærer, at bogen er vandret placeret på bordet.

Desuden er den visuelt opfattede rumlige orientering af artefakter (især beholdere) i mange tilfælde tæt forbundet med deres funktion. For eksempel skal et glas for at opfylde dets primære funktionelle formål, dvs. at tjene som en indretning til at drikke af, være vertikalt orienteret med åbningen pegende opad og bunden nedad mod jorden. Det er derfor sådan, at uafhængigt af deres mål eller dimensioner i øvrigt så peger glassenes åbning opad, når stå anvendes, og den peger sidelæns, når ligge bruges (Hansen 1974/2001: 143). Betydningen af det funktionelle perspektiv bekræftes yderligere af det faktum, at genstande, der er fastgjort til en eller anden form for overflade, sædvanligvis sidder på dansk, jf. (17), (Hansen ibid: 145).

Brugen af positionsverberne stå, sidde og ligge kan man i det hele taget læse meget mere om i Hansens (ibid.) indsigtsfulde og detaljerede artikel om emnet. Pointen med at inddrage stå, sidde og ligge i denne sammenhæng er selvfølgelig at vise, at integration af MÅDE i danske positionsverber og dermed deres indvirkning på det rumlige funktionelle forhold mellem figur og grund jo må siges at spille en ikke ubetydelig rolle med hensyn til, hvordan disse statiske begivenheder udtrykkes og ikke mindst opfattes visuelt. Vender vi tilbage til det komparative-typologiske perspektiv, ville de romanske sprog i lignende tilfælde typisk have tendens til at anvende mådesneutrale lokative verber svarende til vere, altså estar på spansk, dvs. passepartout-verber, der er semantisk 'underpecificerede' med hensyn til at udtrykke den visuelle relation mellem figur og grund.

\subsection{Faste udtryk og prosodi}

I en række tilfælde indgår der sammen med et PP-argument forskellige former for MÅDE-verber i danske faste forbindelser og egentlige idiomer, dvs. flerordsudtryk hvis betydning ikke kan udledes direkte fra de enkelte elementers semantik, jf. (18).

(18) ligge i skilsmisse/ ligge i sengen/sidde i fængsel/ stå i gæld/ gå på universitetet/ gå i skole/ synge i kor

Den semantiske disambiguering af sådanne strukturer er ofte knyttet til prosodi på den måde, at svagtryk på verbet systematisk korrelerer med status af fast udtryk eller idiom, mens verbet i den tilsvarende fuldtryksstruktur bibeholder sin oprindelige betydning (jf. Hansen \& Heltoft 2011 : 337f.). For eksempel betyder de synger $i{ }^{\prime} k o r$, at referenterne for subjektet er 
medlemmer af et kor, de er korsangere, mens de $\left.\right|_{\text {synger }} i \mid$ kor bogstaveligt talt betyder, at subjektsreferenterne udfører syngeaktiviteten sammen i kor. Fuldtryksstrukturen opløser således den faste forbindelse og accentuerer begivenhedens mådesperspektiv.

Uden at gå i dybden med det, er de romanske sprog mig bekendt ikke i stand til, på nogen form for systematisk måde i hvert fald, at danne faste udtryk af den pågældende art på basis af deres inventar af aktivitetsverber, og for så vidt angår spansk er der ikke mulighed for at variere et leksems betydning ved hjælp af prosodiske signaler. Endnu engang kan vi altså konstatere, at dansk adskiller sig fra spansk ved, at MÅDE-komponenten spiller en afgørende rolle i sætningsdannelsen.

\section{Telicitet}

En af nøglerne til at forstå kontrasterne mellem germanske og romanske sprog ligger i deres forskellige evne til at konstruere teliske VP'er på grundlag af aktivitetsverber, her forstået som prædikater, der er dynamiske, durative og ateliske (Vendler 1967).

På dansk kan aktivitetsverber, som indeholder de semantiske komponenter BEVEGELSE og MÅDE i den verbale rod, i det væsentlige anvendes på to måder: Til at udtrykke en enkel, atelisk aktivitet eller til udtrykke en kompleks, telisk begivenhed. Begge strukturer kan så forekomme i en intransitiv såvel som en transitiv version, hvilket indikeres af parentesen omkring det direkte objekt i følgende eksempler.

(19a) Ole sejler (Pia) rundt på Seinen.

(19b) Ole sejler (Pia) til Paris.
[Atelisk]

[Telisk]

Den teliske brug adskiller sig fra den ateliske på den måde, at den kan analyseres som en såkaldt "resultativ small clause (SG)" eller sekundær prædikation, om man vil. ${ }^{8}$

(20a) Ole ${ }_{\mathrm{i}}$ sejler $\left[_{\mathrm{SC}} \varnothing_{\mathrm{i}}\right.$ [til Paris]].

(20b) Ole sejler [ ${ }_{\mathrm{SC}}$ Pia [til Paris]].

8 En nærmere beskrivelse af SC-begrebet findes hos Hoekstra (1988). 
I (20b) bliver det direkte objekt Pia subjekt for et temporalt umarkeret PPprædikat til Paris, mens subjektet for til Paris i (20a) er matrixsætningens subjekt Ole. Det betyder, at det i begge tilfælde er det interne argument, det direkte objekt i (20b) og det intransitive subjekt i (20a), som er i stand til at danne en SC med PP-prædikatet. SC'en angiver den resulterende tilstand, der følger af den agentive begivenhed, der udtrykkes af hovedverbet, og markerer således slutpunktet for sejlebegivenheden, hvilket gør hele sætningen telisk.

Den samme analyse finder anvendelse på de strukturer, hvor verbet denoterer en aktivitet, men ikke samtidigt indebærer, at figuren bevæger sig væk fra udgangspositionen, jf. (2 lab) (se også 9 og 10). Dog er der ikke her tale om, at der er variationsmulighed mellem en transitiv og intransitiv version.

(21a) Jonathan kysser Pernille.

[Atelisk]

(21b) Jonathan kysser [ ${ }_{\mathrm{SC}}$ Pernille [ind i Folketinget]]. [Telisk]

Endelig skal det nævnes, at spansk faktisk i forbindelse med visse bevægelsesverber - ifølge Pedersen (2010: 172-180) hovedsageligt hvis de refererer til en såkaldt retningsbestemt bevægelsessituation - har muligheden for at danne teliske strukturer, der er parallelle til de danske, jf. fx nedenstående eksempel.

$\begin{array}{llllll}\text { A-l } & \text { amanec-er } & \text { rema-ron } & \text { a } & \text { la } & \text { orilla. } \\ \text { til-ART } & \text { lysne-INF } & \text { ro-PST } & \text { til } & \text { ART } & \text { bred }\end{array}$

'Ved daggry roede de ind til bredden.'

(Müller 2014: 124)

Vigtigt er det dog som sagt at holde fast i, at der for så vidt angår spansk ikke er tale om et særskilt produktivt fænomen (Pedersen ibid.: 179-180) eller en systematisk, generaliseret alternationsmulighed, som det er tilfældet på fx dansk.

\section{Konklusion}

Man kan overordnet konstatere, at genetisk nært beslægtede sprog som dansk og spansk alligevel er ret forskellige typologisk set.

Dansk har en stor mængde aktivitetsverber, der enten kan udtrykke selve aktiviteten eller dens kulmination i et endepunkt, dvs. optræde telisk, og så 
har vi en lille gruppe positionsverber, der også, ligesom aktivitetsverberne, indeholder en MÅDE-komponent.

Et sprog som spansk har ligeledes en stor gruppe aktivitetsverber, men i modsætning til dansk er deres distribution begrænset i den forstand, at de kanonisk ikke kan bruges til at udtrykke tilstandsændringer, dvs. fungere som teliske prædikater. Positionsverber, der indeholder en MÅDE-komponent, findes stort set ikke på spansk.

Modsat dansk har spansk så en gruppe verber, der inkorporerer BEVÆGELSE og RETNING i verbalroden, og som kan anvendes telisk. Spansk kan selvfølgelig også udtrykke måde-relateret information, men det foregår som regel enten via adverbielle modifikatorer, eller også kan måden, en aktivitet udføres på, udledes af konteksten og nævnes derfor ikke eksplicit. Spansk har således minimal fokus på MÅDE, mens danske MÅDE-verber bruges hyppigt og fleksibelt som sætningens leksikalske hovedverbum.

På den baggrund er det nærliggende at spekulere over, om ikke disse markante forskelle har betydning for, hvordan vi ser og opfatter begivenheder. På trods af, at det her fremlagte ikke er baseret på eksperimentelle data, kan man med udgangspunkt i de i artiklen behandlede eksempler antage, at MÅDE udgør en grundlæggende kognitiv kategori, der ansporer dansktalende til at fokusere på begivenheder som visuelle manifestationer af virkeligheden, dvs. til konkret at forestille sig, hvordan en figur bevæger sig eller er placeret i forhold til grunden. Som antydet flere gange, bevirker det specifikke valg af verballeksem i en given sammenhæng, at både taler og lytter må skabe et mentalt billede af, hvordan den pågældende aktivitet konkret foregår. Det gælder også ved statiske beskrivelser, at kommunikationsparterne tvinges til at visualisere figuren, dens funktion og dens specifikke position i forhold til grunden. Med andre ord fører den systematiske præference for at udtrykke måde på dansk til, at man må være i stand til at foretage en visuel identifikation af situationen og dens deltagere.

Spansk medfører ikke en sådan visuel konceptualisering af begivenheder. Snarere lægges der op til, at man ser begivenheder som abstrakte aktiviteter eller positionelt non-specifikke figur-grund arrangementer. Typisk er den sproglige kodning af begivenheder på spansk og andre romanske sprog underspecificeret med hensyn til omstændighederne, under hvilke begivenhederne udvikler sig, dvs. at måden kan udledes af sammenhængen eller simpelthen er uinteressant. Det antages altså, at de typologiske forskelle, der er blevet behandlet i artiklen, ikke bare har konsekvenser for sproglig struktur i form af morfologi og syntaks, men også for hvordan begivenheder i bred forstand opfattes. 


\section{Om forfatteren}

Henrik Høeg Müller, ph.d., dr.ling.merc., Institut for Kommunikation og Kultur, Aarhus Universitet.

\section{Litteratur}

Akita, K. (2017): The typology of manner expressions: A preliminary look. I: Ibarretxe-Antuñano (red.) Motion and Spaces across Languages. Amsterdam/Philadelphia: Benjamins, 39-60.

Baron, I. (2014) : Langue et publicité: corrélation et isomorphism. I: Korzen, A. Ferrari \& A.M. De Cesare (red.). Tra romanistica e germanistica: lingua, testo, cognizione e cultura/Between Romance and Germanic: Language, text, cognition and culture. Bern: Peter Lang, 295-314.

Beavers, J., B. Levin \& T. Shiao Wei (2010): The Typology of Motion Expressions Revisited, Fournal of Linguistics 46, 331377.

Bergh, L. (1948): Moyens d'exprimer en français l'idée de direction. Étude fondée sur une comparaison avec les langues germaniques en particulier le suédois, Thèse pour le doctorat, Göteborgs Universitet.

Croft, W.A., J. Barðdal, W.B. Hollmann, V. Sotirova \& C. Taoka (2010): Revising Talmy's Typological Classification of Complex Event Constructions. I: Boas, H.C. (red.). Contrastive Construction Grammar. Amsterdam/ Philadelphia: Benjamins, 201-235.

Hansen, E. (2001/[1974]): Stå, sidde, ligge, i H. Galbjerg Jacobsen \& H. Jørgensen (red.) Gladen ved grammatik. København: Hans Reitzels Forlag, 274-282.

Hansen, E. \& L. Heltoft (2011): Grammatik over det Danske Sprog. København/ Odense: Det Danske Sprog- og Litteraturselskab/Syddansk Universitetsforlag.

Herslund, M. (2014): Mouvement et déplacement: typologie des verbes de movement en roman et en germanique. I: Korzen, I., Ferrari, A. \& De Cesare, A-M. (red.) Between Romance and Germanic: Language, text, cognition and culture. Bern: Peter Lang, 75-94.

Herslund, M. \& I. Baron (2005): Langues endocentriques et langues exocentriques. Approche typologique du danois, du français et de l'anglais. I : Herslund, M. \& Baron, I. (red.). Le génie de la langue française. Perspectives typologiques et contrastives. Langue française 145, 35-53.

Hoekstra, T. (1988): Small Clause Results, Lingua 74, 101-139.

Korzen H. (2003): Attribut de l'object et valence dérivée. Étude contrastive 
dano-française. I: Herslund, M. (red.) Aspects linguistiques de la traduction. Bordeaux: Presses Universitaires de Bordeaux, 85-102.

Korzen, H. (2004): Les attributs indirects en français et en danois: Différences typologiques et problèmes de traduction, i G. Hansen, Malmkjaer, G. \& Gile, D. (red.) Claims, Changes and Challenges in Translation Studies, 73-81.

Levin, B. \& M. Rappaport Hovav (1995): Unaccusativity: At the Syntax-Lexical Semantics Inter face. Cambridge, Mass: The MIT Press.

Malblanc, A. (1944): Pour une stylistique comparée du français et de l'allemand: Essai de représentation linguistique compare. Paris: Didier.

Morita, T. (2011): Intratypological Variations in Motion Events in Japanese and French, CogniTextes [En ligne], 6.

Müller, H.H. (2014): Framing of motion events in Danish and Spanish. Some remarks on lexicon vs. usage. I: Korzen, I., Ferrari, A. \& De Cesare, A-M. (red.) Between Romance and Germanic: Language, text, cognition and culture. Bern: Peter Lang, 115-135.

Pedersen, J. (2009): The Construction of Macro-events. A typological perspective. I: Deconstructing constructions. Butler, I.C. \& Arista, J.M. (red.). Amsterdam/New York: Benjamins, 25-62.

Pedersen, J. (2010): Marginal brug af mådesverber i spanske bevægelsesudtryk. Typologisk status. I: Ny Forskning i Grammatik 17. Birkelund, M., Dam, L., Dam-Jensen, L.H. \& Fernández, S.S. (red.). Odense: Syddansk Universitet, 167-194.

Slobin, D.I. (2004): The many ways to search for a frog: linguistic typology and the expression of motion events. I: S. Strömqvist \& Verhoeven, L. (red.) Relating events in narrative: Typological perspectives. Mahwah, N. J.: Erlbaum, 219-257.

Slobin, D.I. (2006): What Makes Manner of Motion Salient? Explorations in Linguistic Typology, Discourse, and Cognition. I: M. Hickmann, \& Robert, S. (red.) Spaces in Languages: Linguistic Systems and Cognitive Categories. Amsterdam/Philadelphia: Benjamins: 5982.

Strohmeyer, F. (1924): Der Stil der französischen Sprache. Berlin: Weidmann.

Talmy, L. (1985): Lexicalization patterns: semantic structure in lexical forms. I: Shopen, T. (red.) Language typology and syntactic description, vol. III, Grammatical categories and the lexicon. Cambridge: Cambridge University Press, 57-149.

Talmy, L. (2000): Toward a Cognitive Semantics, vol. II: Typology and Process in Concept Structuring. Cambridge, Mass.: MIT Press.

Vendler, Z. (1967): Verbs and times.Linguistics in philosophy. Ithaca: Cornell University Press, 97-121. 
Vinay, J.P. \& J. Darbelnet (1958): Stylistique Comparée du Français et de l’Allemand. Paris: Didier.

Woldersgaard, G.A.G. (2017): Lexicalisation Patterns in Danish and Spanish, Ph.d.-afhandling, School of Business and Social Sciences, Aarhus Universitet, 597 sider. 